\title{
THE LIFE AND DEATH OF ARTHUR DOBBS
}

\section{MATTHEW M. KAELIN・Bellmore・New York•USA・mattfromquogue@aol.com}

Dark waters were churning beneath the vessel as we crossed the Cape Fear River on our way to visit the grave of old Arthur Dobbs.

For those of you who do not know about Arthur Dobbs (Fig. 1), he was the Colonial Governor of North Carolina from 1754 to 1765 and is the person who made the discovery of the Venus Flytrap around 1758. Born April 2 ${ }^{\text {nd }}, 1689$ to Richard Dobbs and Mary Stewart Dobbs, he would inherit Castle Dobbs in Carrickfergus, Northern Ireland, which was founded by his ancestors who emigrated from Scotland in the 1500 's. He married the young widow Anne Osburn Norbury on the $12^{\text {th }}$ of May in 1719 and fathered three sons and a daughter. A highly-accomplished individual, he served as the Engineer-in-Chief and Surveyor-General of Ireland, High Sheriff of Antrim, and an elected member of the Irish Parliament. In his spare time, he was also an avid naturalist being the first person to recognize the pollination of flowers by bees authoring "Concerning Bees and their methods of Gathering Wax and Honey" for the Royal Society in 1750 as well as several articles on astronomy.

With a keen interest in the British Colonies of North America, Arthur Dobbs purchased 400,000 acres in North Carolina in 1745 and eventually would own 1,300,000 acres. Sadly, he lost his wife Anne after 28 years of marriage in 1747 and became so distraught from her death that he accomplished little over the following three years. He then decided to leave his estate in the care of his eldest son and set out for the New World when he gained the appointment by the British Crown to become the next Governor of North Carolina.

When not fulfilling his numerous official duties, Arthur Dobbs could frequently be seen in Brunswick following bees to chart their flight, recording the weather, and getting onto his hands and knees to investigate the new and unusual plants he had never seen back home in Ulster.

Then on his $70^{\text {th }}$ birthday on April $2^{\text {nd }}, 1759$, he wrote a letter to English naturalist Peter Collinson, in which he states "I have taken a little plantation at the sound on the sea coast. We have a kind of a Catch Fly Sensitive which closes upon anything that touches it. It grows in the Latitude 34 but not in 35. I will try to save the seed here. Your most humble servant, Arthur Dobbs." He sent one of these unusual plants to John Bartram in England, who was Royal Botanist to King George III for the North American Colonies and who is also the person thought to have conjured the name "Tippitiwitchet" for the plant. Rumored to be of American Indian origin, it has been proven to not be as there is no such word in the Native American languages. In fact, it is thought to be a slang word used for the female genitalia. So here we see that the predominate characteristic that this group of men think

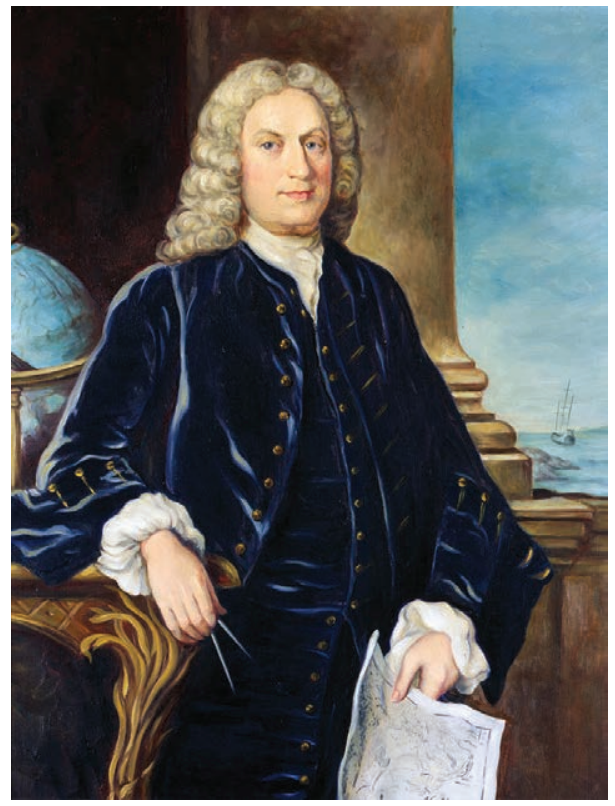

Figure 1: Arthur Dobbs. Photo courtesy of North Carolina Museum of History, with permission. 
of when they see this new wonder of the botanical world, the likes never seen before is, in fact, the likeness of a woman's most personal anatomy.

Arthur Dobbs seemed to lose interest in our most famous carnivorous plant species, for in 1762 as a widower for 15 years and at the age of 73, he married Justina Davis, granddaughter of Governor James Moore of South Carolina, who at 15, was 58 years his junior. In a letter to John Bartram on 29 August 1762, Peter Collinson wrote: "It is now in vain to write to him for seeds or plants of Tipitiwitchet now He has gott one of his Own to play with." This would be appalling today and was, in fact, quite scandalous even in its time. In a particularly scathing attack perhaps guided more by politics, as Dobbs' age was actually five years younger than claimed, we hear the colorful statement: "Our old silenus of the envigorated age of seventy eight who still damns this province with his baneful influence grew stupidly enamored with Miss Davis a lovely lady of sprightly fifteen of a good family and some fortune." Although despite the wide age difference, it does appear that this was a warm, loving marriage. Especially seen in their writings addressed to their friends and families where they mentioned one another with such tender and dear manners.

Unfortunately, within just a few months after their marriage, Dobbs suffered a stroke which confined him to a wheelchair for the rest of his life. His young wife nursed him back to health and he eventually recovered enough to carry on with his official duties for a couple of more years until he decided to retire and return to Ireland with his beloved Justina. She was described to be quite excited about this, but only two weeks before they were to depart, Dobbs suffered a seizure and two days later, on 28 March 1765, Arthur Dobbs died in Justina's arms. He was buried on the grounds of St. Philip's (Fig. 2), the Anglican Church Dobbs sought to complete, far away from his family estate in Ireland and his first wife Anne.

Justina was described as being almost inconsolable from her loss, but being very eligible at 18 years old, beautiful and well-connected in high society, she found herself approached by many suitors. After her grieving had passed, she married an attorney and legislator from Halifax, the 26-year-old Abner Nash. She bore him three children before she died in 1773 at only 26 years old and was laid to rest in Halifax. Abner would later remarry and become Governor of North Carolina, where eventually he would be buried on his plantation in Pembroke near New Bern and so Justina was left buried alone, more than a hundred miles from either of her husbands, forever fated to rest in solitude.

As we cross the turbulent Cape Fear River and I contemplate this history, my mind wanders and begins to imagine a wistful tale where deep in the night, when the light of the moon shines through a heavy mist that hangs over the land, one can make out the figures of Arthur Dobbs and Justina Davis meandering on a romantic stroll through the meadows where flytraps grow, holding one another's hands and delightfully laughing as carefree and in love everlasting. Lost souls that they are, having

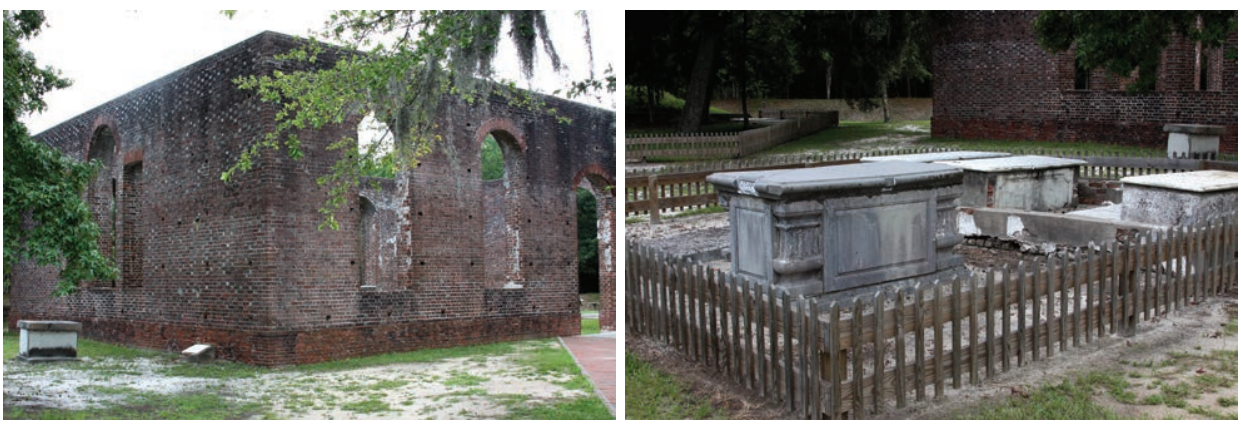

Figure 2: St. Philip's Church ruins and cemetery, Brunswick Town, North Carolina. 
been buried alone and forgotten by all, they restlessly rise from their graves to rendezvous with one another for the time they had together on this earth was all too brief with their ages widely disparate. And now, they have all of eternity to love and frolic as their ageless entities are no longer bound by such worldly constraints.

My vision then darkens and turns to when the ghosts of Arthur and Justina would come across a person poaching flytraps from the wild, their graceful and ethereal figures would burst into a blazing fury of hellfire, their forms contorting into grotesque and burning skeletal demons that rush the poacher in a screaming tempest, ripping apart the victim's body to bits that rain down feeding the thousands of little mouths of the flytraps below, eagerly gaping to feast upon this flesh as the cascades of blood spill to saturate the soil while the remaining bones smolder to dust and blow away with gusts of the passing wind.

And now we finally make landfall, with the salt-sea to our backs, we set forth for the ruins of the Saint Philip's Church to pay homage to the final resting place of Arthur Dobbs.

\section{Sources:}

http://susan747.wordpress.com/2010/02/21/gov-arthur-dobbs-and-a-trip-to-ireland/ http://news.google.com/newspapers?nid=1734\&dat=19770531\&id=9nwcAAAAIBAJ\&sjid=

kVEEAAAAIBAJ\&pg $=5877,2853690$

http://www.sarracenia.com/faq/faq2880.html http://www.thepeerage.com/p38310.htm
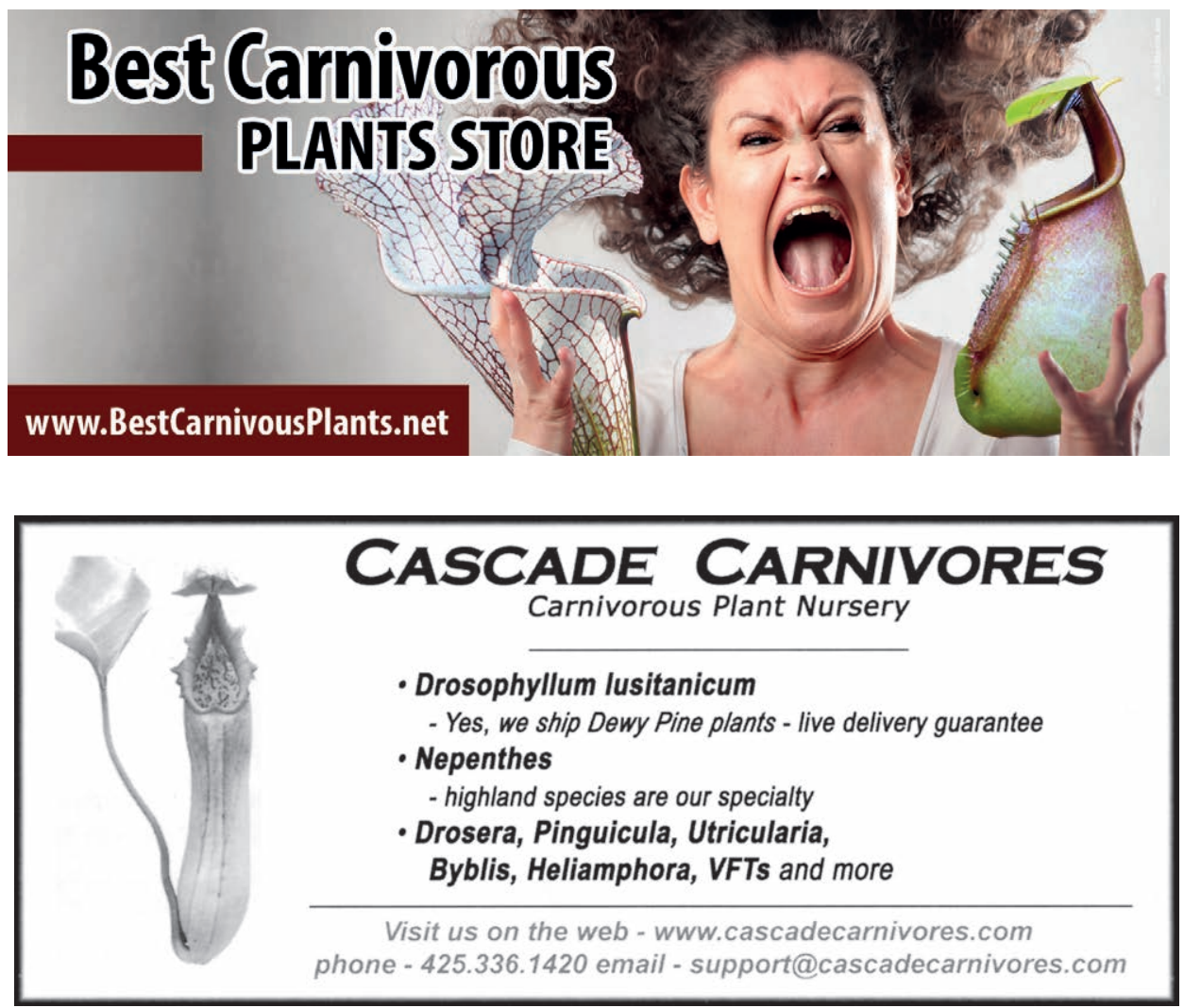